\title{
Impact on Renewable Design Requirements of Net-Zero Carbon Buildings under Potential Future Climate Scenarios
}

\author{
Dongsu Kim ${ }^{1}$, Heejin Cho ${ }^{2, *(\mathbb{D}}$, Pedro J. Mago ${ }^{3}$, Jongho Yoon ${ }^{1}$ and Hyomun Lee ${ }^{1}$ \\ 1 Department of Architectural Engineering, Hanbat National University, Daejeon 34158, Korea; \\ dongsu.kim@hanbat.ac.kr (D.K.); jhyoon@hanbat.ac.kr (J.Y.); leehm0831@gmail.com (H.L.) \\ 2 Department of Mechanical Engineering, Mississippi State University, 210 Carpenter Engineering Building, \\ P.O. Box 9552, Mississippi State, MS 39762, USA \\ 3 Department of Mechanical and Aerospace Engineering, West Virginia University, Morgantown, WV 26506, \\ USA; pedro.mago@mail.wvu.edu \\ * Correspondence: cho@me.msstate.edu; Tel.: +1-662-325-1959
}

check for

updates

Citation: Kim, D.; Cho, H.; Mago, P.J.; Yoon, J.; Lee, H. Impact on Renewable Design Requirements of Net-Zero Carbon Buildings under Potential Future Climate Scenarios. Climate 2021, 9, 17. https://doi.org/ 10.3390/cli9010017

Received: 27 December 2020

Accepted: 17 January 2021

Published: 19 January 2021

Publisher's Note: MDPI stays neutral with regard to jurisdictional claims in published maps and institutional affiliations.

Copyright: (c) 2021 by the authors. Licensee MDPI, Basel, Switzerland. This article is an open access article distributed under the terms and conditions of the Creative Commons Attribution (CC BY) license (https:// creativecommons.org/licenses/by/ $4.0 /)$.

\begin{abstract}
This paper presents an analysis to foresee renewable design requirement changes of netzero carbon buildings (NZCBs) under different scenarios of potential future climate scenarios in the U.S. Northeast and Midwest regions. A climate change model is developed in this study using the Gaussian random distribution method with monthly temperature changes over the whole Northeast and Midwest regions, which are predicted based on a high greenhouse gas (GHG) emission scenario (i.e., the representative concentration pathways (RCP) 8.5). To reflect the adoption of NZCBs potential in future, this study also considers two representative future climate scenarios in the 2050s and 2080s of climate change years in the U.S. Northeast and Midwest regions. An office prototype building model integrates with an on-site photovoltaics (PV) power generation system to evaluate NZCB performance under the climate change scenarios with an assumption of a net-metering electricity purchase agreement. Appropriate capacities of the on-site PV system needed to reach NZCB balances are determined based on the building energy consumption impacted by the simulated climate scenarios. Results from this study demonstrated the emission by electricity consumption increases as moving toward the future scenarios of up to about 25 tons of $\mathrm{CO}_{2}$-eq (i.e., about $14 \%$ of the total $\mathrm{CO}_{2}$-eq produced by the electricity energy source) and the PV installation capacity to offset the emission account for the electricity consumption increases significantly up to about $40 \mathrm{kWp}$ (i.e., up to more than $10 \%$ of total PV installation capacities) as the different climate scenarios are applied. It is concluded that the cooling energy consumption of office building models would significantly impact GHG emission as future climate scenarios are considered. Consequently, designers of NZCBs should consider high performance cooling energy systems in their designs to reduce the renewable energy generation system capacity to achieve net-zero carbon emission goals.
\end{abstract}

Keywords: net-zero carbon building; climate change; EnergyPlus; building energy modeling; office building; photovoltaics (PV)

\section{Introduction}

The building sector accounts for approximately $40 \%$ of the total end-use energy consumption (i.e., primary and secondary energy usages) in the United States [1], including about $21 \%$ and $18 \%$ for residential and commercial buildings, respectively. In the commercial building sector, about $74 \%$ of the energy consumption was captured for the electric power sector to generate and supply electricity retails. The U.S. Energy Information Administration (EIA) also estimated that electricity use in the commercial building sector was expected to increase by about $14 \%$ by 2050 compared to levels in 2019 [2]. This growth has led to concerns regarding the future increased energy consumption and human emission of carbon dioxide $\left(\mathrm{CO}_{2}\right)$ from the building sector. According to the Congressional Research Service reports $[3,4]$, it was pointed out that the electric power sector contributed the 
second-largest percentage, $35 \%$ of U.S. $\mathrm{CO}_{2}$ emission contributions based on the 2017 U.S. $\mathrm{CO}_{2}$ emission contribution data by sectors. Within the building sector, the commercial sector presented more than $37 \%$ of the electric power sector's $\mathrm{CO}_{2}$ contributions. Although the amount of electricity power generation had remained flatted after 2010, $\mathrm{CO}_{2}$ emissions continued a general trend of reduction after 2007 mainly because of increased renewable sources and natural gas use as well as reduced coal use in electricity generation, resulting in a $20 \%$ reduction of $\mathrm{CO}_{2}$ emissions when compared to the $\mathrm{CO}_{2}$ emissions levels of 2005 [3,4] However, there are still concerns regarding greenhouse gas (GHG) emission and global warming issues as the global growth rate of GHG emission from human activities has still increased [5-7].

As an effort to reduce GHG emission, the concept of net-zero carbon emission buildings (NZCBs) has been developed, and the idea has been gaining significance globally to achieve feasible long-term goals of GHG emission reductions for the coming decades [8]. To appropriately implement the NZCB concept, high energy-efficient appliances and systems must be encouraged [9], and an appropriate selection and design of on-site renewable energy systems must be incorporated to effectively reduce both on-site and central generation of GHG emission [10,11]. Louwen et al. [12] presented a good overview of the impact of GHG emission by PV-based renewable energy generation. They reviewed over 40 years of PV development and analyzed energy demand and GHG emission impacts in terms of PV production. Their results illustrated that when the doubling of installed PV capacity occurred, energy consumption and GHG emission could be decreased by about $13 \%$ and $17-24 \%$, respectively. Pinel et al. [13] evaluated the impact of allowing to buy $\mathrm{CO}_{2}$ compensation to enable the zero emission neighborhoods design. They pointed out that there were large differences in energy system design and GHG emission generation depending on variations in weather conditions and the price of external compensation.

Researchers have conducted numerous studies on climate change impacts on building energy consumption. Wan et al. [14] investigated building energy use variations based on climate change scenarios in subtropical climates. They demonstrated that improving efficiencies in building components, such as lighting and chiller, can provide potential mitigation for increased future energy use due to climate changes in the late 21st century. Nik and Kalagasidis [15] assessed possible climate changes and uncertainties in future energy performance of the residential building stock in Stockholm. Four uncertainty factors (i.e., global climate models, regional climate models, emissions scenarios, and initial conditions) were considered in their study, and they pointed out that all their climate change scenarios up to 2100 showed that the future heating demands would be decreased by about $30 \%$ compared to the date before 2011 while the cooling demand would increase mainly because of increased outdoor air temperatures. Kikumoto et al. [16] constructed future standard weather data for use in building design and energy analysis for 2030s (i.e., 2031-2035). Based on their study, it was observed that there would be a substantial impact of climate change on the energy performance of a detached house, including $15 \%$ increases in sensible heat loads predicted under their study condition. Shen [17] evaluated the energy consumption variation of residential and commercial buildings by climate change scenarios in four representative cities in the U.S. using EnergyPlus. They showed that climate changes could have potential impacts on residential and office building energy usages during the years $2040-2069$, including $-1.64 \%$ to $14.07 \%$ and -3.27 to $-0.12 \%$ of annual energy changes for residential and office buildings, respectively. Wang et al. [18] presented energy simulation-based analysis to investigate impacts of climate change on building energy consumptions in U.S. climate zones. The EnergyPlus medium office prototype model was used to predict energy consumption with two different climate change models, including Hadley Centre Coupled Model version 3 and NCAR Community Earth System Model version 1. With their generated future weather files, they examined that climate change mitigation measures related to heating, ventilation, and air conditioning (HVAC) operations such as adjustment of thermostat setpoints and reduced HVAC operation hours. In addition, Summa et al. [19] compared energy consumption of a 
current residential NZEB in Rome, Italy with that expected in 2050 under Representative Concentration Pathway (RCP) 4.5 and 8.5 scenarios. Their results showed that about $50 \%$ of increases in cooling energy use were presented, while heating energy use showed significant decreases under the future climate changes.

Although there have been several pieces of research investigating building energy use due to climate changes, there is still a lack of studies understanding the adoption of NZCBs associated with future potential climate changes in a quantitative manner in the literature [20]. To fill this research gap, this paper investigates the impact of climate changes on commercial building energy consumption and carries out an analysis to foresee renewable design requirements of NZCBs under different scenarios of future climate changes in the U.S. Northeast and Midwest regions. The medium-sized office prototype building model, which complies with a widely and globally accepted commercial building energy standard (i.e., ASHRAE Standard 90.1-2019 [21]), is subjected in this study to evaluate NZCB design requirements under different climate change scenarios. The focus of this paper is to provide useful insights into variations in building energy consumption and renewable design requirements when office buildings are subjected to a net zero carbon design under the current typical meteorological year (TMY) data and future climate scenarios. It is important to note that this paper does not investigate different strategies for enabling net zero carbon operations to commercial buildings, e.g., advanced building envelope and HVAC technologies to reduce building energy consumption.

\section{Methodology}

\subsection{Description of Climate Change Model}

This section describes the methodology to generate climate change data for building energy simulations. Various weather conditions, including dry-bulb temperature, wet-bulb temperature, solar radiation, relative humidity, and wind speed/direction, can impact the building thermal load. Such factors can be considered in comprehensive building energy modeling and prediction to estimate energy consumption in a building. Typical meteorological year 3 (TMY3) weather data [22], which is statistically derived annual climate data, is used in the building energy simulations of this study. Our previous study [23] revealed that the ambient temperature is a dominant contributing factor to the thermal load during both heating and cooling seasons among all weather variables. Therefore, predicted changes in the dry-bulb temperature of outdoor air are assumed to be a single dominant variable for the climate change model in this study. A stochastic method using the normal distribution with a random sampling technique is applied to generate future weather profiles for building energy simulation. The probability density function of the normal distribution is defined as:

$$
p(x)=\frac{1}{\sqrt{2 \pi \sigma^{2}}} e^{-\frac{(x-\mu)^{2}}{2 \sigma^{2}}}
$$

where $\mu$ is the mean value and $\sigma$ is the standard deviation, and the standard deviation is assumed to be one (1) in this study. As the value of $\sigma$ increases, the range of potential random errors also increases, therefore, this study considers appropriate distribution patterns by assuming the standard deviation of the predicted dry-bulb temperature to be $1{ }^{\circ} \mathrm{C}$ to ensure that the adjacent hourly temperature does not deviate more than $2{ }^{\circ} \mathrm{C}$. The mean values of the predicted dry-bulb temperature are determined based on the study conducted by Byun et al. [24].

The Byun's model [24] was developed based on hydrologic modeling experiments over 20 Midwestern watersheds using the Variable Infiltration Capacity (VIC) model forced by historical observed datasets and future projections from the statistically downscaled Global Climate model (GCM). Their model provides monthly projected changes in hydrometeorolgical variables over the whole Midwest and Northeast regions, including precipitation, outdoor air temperature, evapotranspiration, and soil moisture. The projected monthly temperature changes from the Byun's model are used to generate future 
weather files for all selected locations in this study. Figure 1 presents the temperature changes of the Byun's model for two representative scenarios of future study periods (i.e., 2050s and 2080s). The future weather projections in Byun's study are based on two GHG concentration scenarios, including Representative Concentration Pathway (RCP) 4.5 and 8.5 for medium and high cases, respectively. The two scenarios are based on 30-year windows centered on the 2050s (2041-2070) and 2080s (2071-2100).
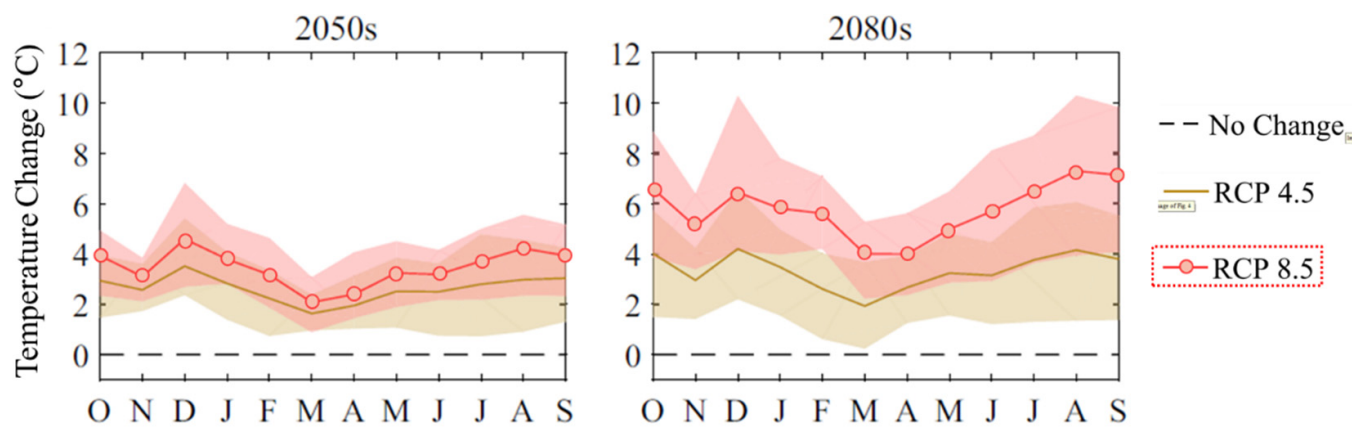

Figure 1. Monthly projected changes in the outdoor air temperature [24]. RCP: Representative concentration pathways.

The RCP 8.5 model's projection shown in Figure 1 is selected in this study to generate random distributions of temperature changes with the scenarios with an assumption of a high-emission scenario. Monthly mean values of outdoor air temperature changes are determined from the Byun's RCP 8.5 model shown in Table 1. These mean values are used in the probability density function in Equation (1) to generate random distributions of hourly temperature variations for each climate change scenario in different climate locations. Table 1 summarizes monthly mean values of outdoor air temperature changes extracted from the Byun's RCP 8.5 model.

Table 1. Monthly mean values $(\mu)$ of outdoor air temperature changes obtained from [24].

\begin{tabular}{ccccccccccccc}
\hline & Jan. & Feb. & Mar. & Apr. & May & Jun. & Jul. & Aug. & Sep. & Oct. & Nov. & Dec. \\
\hline $2050 \mathrm{~s}$ & 3.9 & 3.1 & 2.2 & 2.4 & 3.2 & 3.1 & 3.5 & 4.2 & 4.0 & 4.0 & 3.2 & 4.8 \\
$2080 \mathrm{~s}$ & 6.0 & 5.8 & 4.1 & 4.0 & 5.0 & 5.8 & 6.1 & 7.5 & 7.2 & 6.3 & 5.3 & 6.3 \\
\hline
\end{tabular}

Three locations, including New York, NY, Buffalo, NY, and Rochester, MN, in the U.S. Northeast and Midwest regions are chosen to evaluate the impact of climate change on the building's energy use. Those locations are selected because they can represent three different climate zones in the U.S. Northeast and Midwest regions defined by ASHRAE 90.1-2019, i.e., climate zones $4 \mathrm{~A}, 5 \mathrm{~A}$, and $6 \mathrm{~A}$, which can show variations in net zero carbon requirement and design within the same region. Hourly temperature changes of the scenario in the 2050s and 2080s are randomly generated separately for each climate location using the mean values in Table 1 and Equation (1). Figures 2 and 3 show monthly distributions of randomly generated hourly temperature changes for the scenario in the 2050s and 2080s, respectively, in climate location 4A New York, NY. Note that the dotted line in each plot indicate the mean value of each month, and each bin size in the histogram is determined based on the number of hourly temperature change data in each month and scenario. Figure 4 shows climate change patterns of hourly temperatures corresponding to each scenario in the selected locations. 

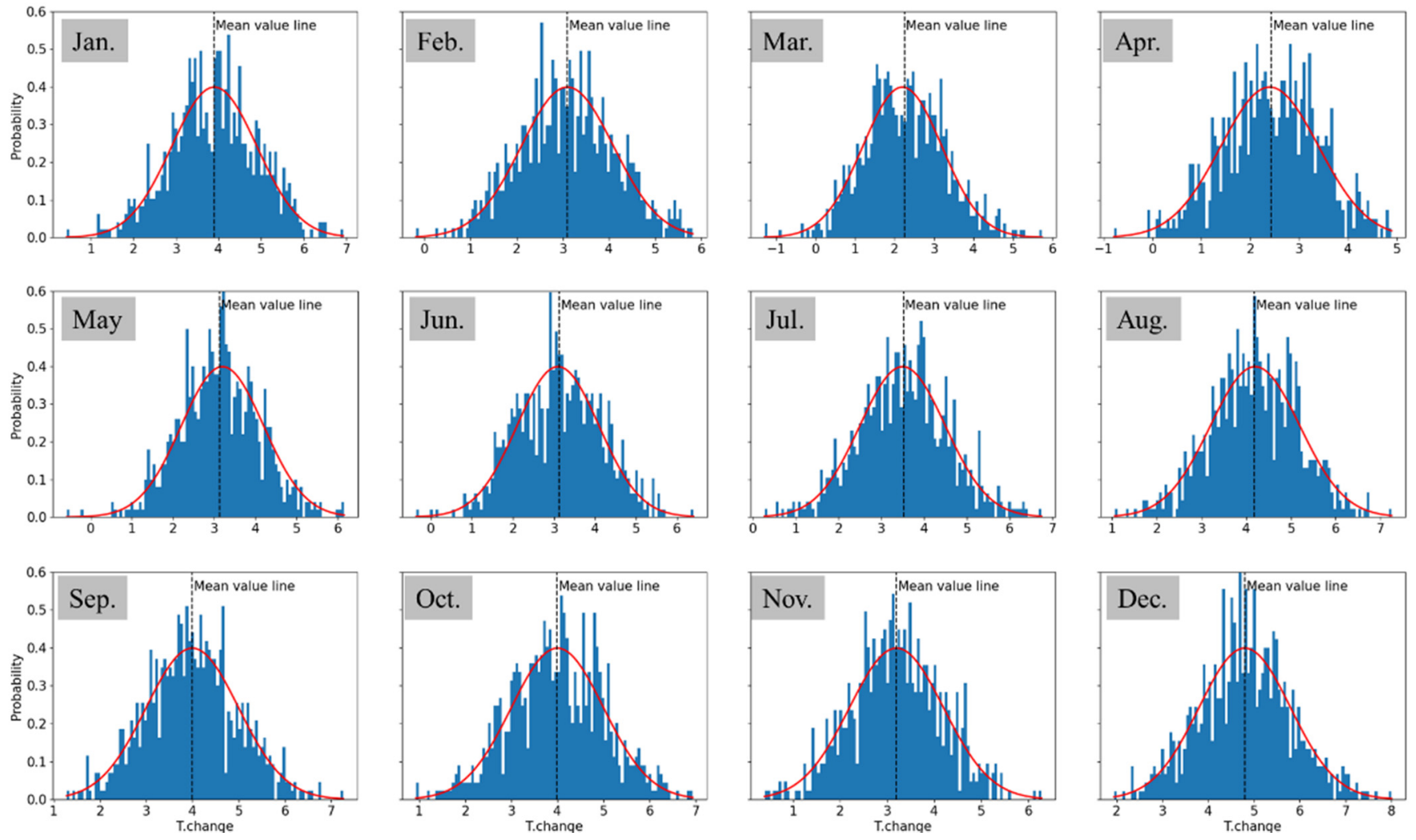

Figure 2. Monthly distributions of hourly temperature changes for scenario the 2050s in 4A New York, NY.
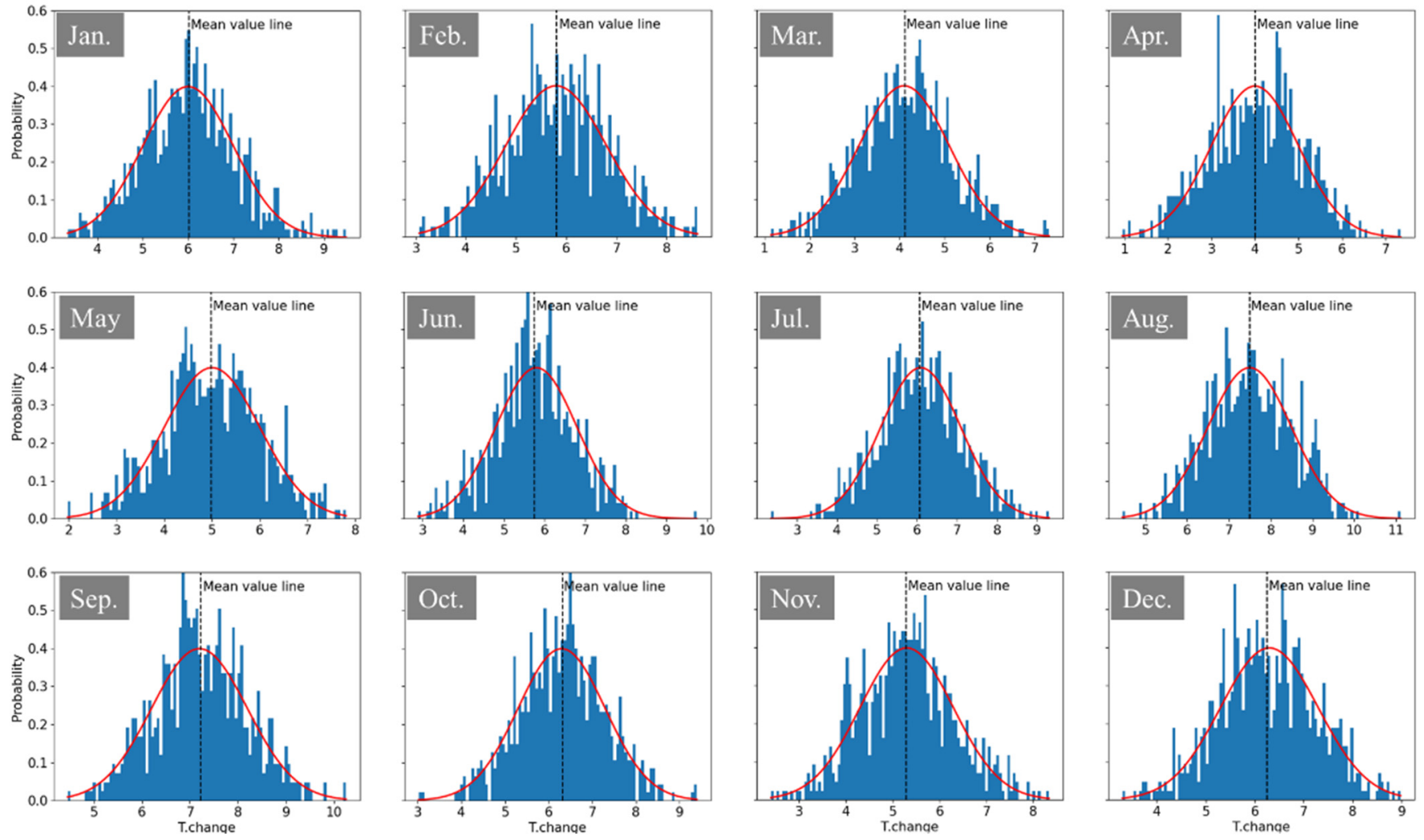

Figure 3. Monthly distributions of hourly temperature changes for scenario the 2080s in 4A New York, NY. 


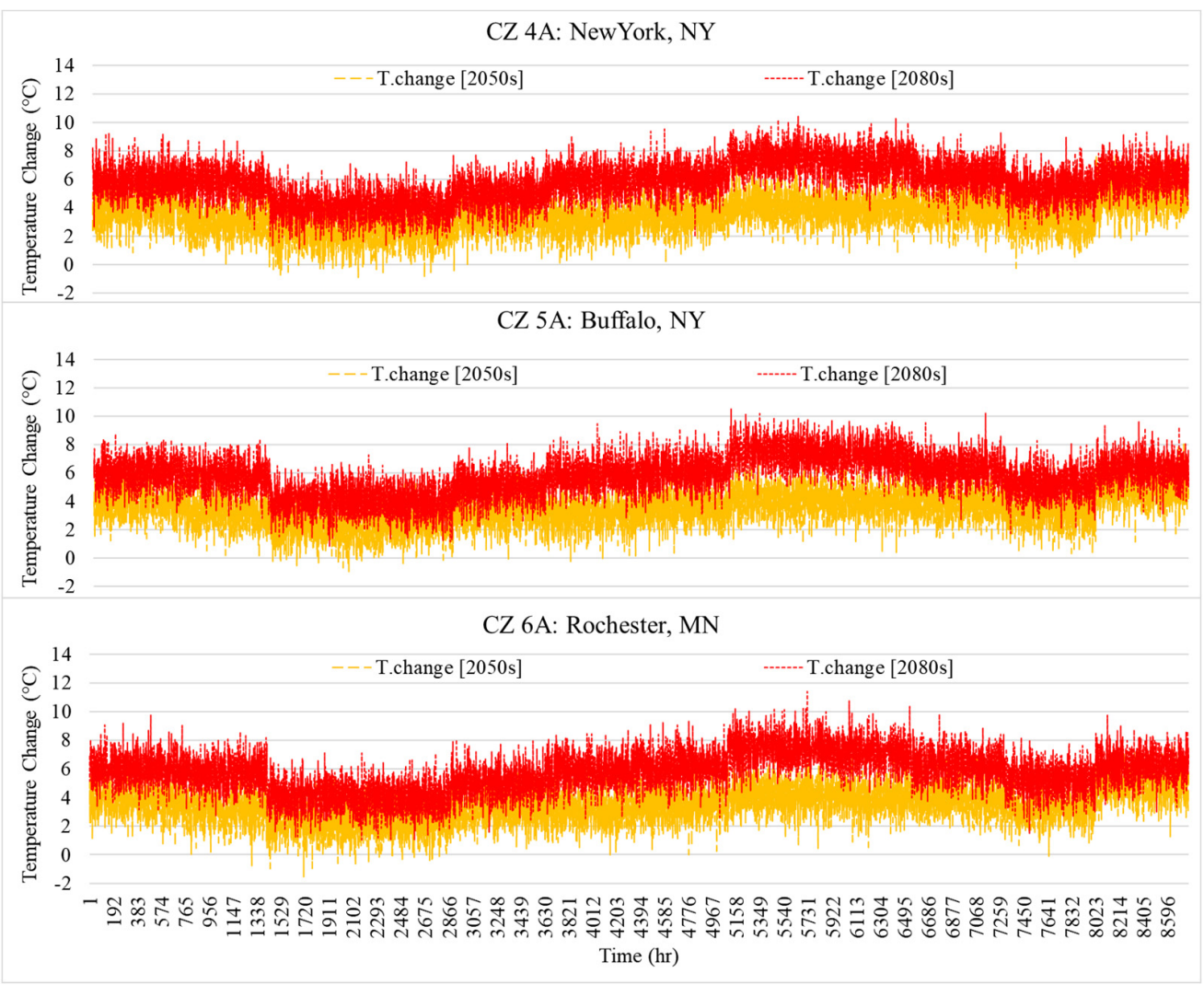

Figure 4. Hourly changes in generated temperature based on the two different scenarios.

This study uses typical meteorological year version 3 (TMY3) weather data [25] for the hourly building energy simulations. The TMY3 weather dataset was created using data collected over a 1991-2005 period based on the procedures developed by National Renewable National Laboratories, and its dataset covers more than 1000 locations in the U.S. [25]. This study assumes that the TMY3 weather data would represent typical weather conditions in the present time in the selected climate locations, and it is used as a baseline weather scenario for climate change analysis. To generate the weather scenario in the 2050s and 2080s, TMY3 weather datasets are modified to reflect the climate changes shown in Figure 4. More specifically, the hourly outdoor air dry-bulb temperatures in the TMY3 weather data file in each location are modified to determine the weather scenario in the $2050 \mathrm{~s}$ and 2080s. The modified hourly dry-bulb temperatures $\left(T_{O A, \text { modified }, i}\right)$ for the weather scenario in the 2050s and 2080s can be determined by:

$$
T_{O A, \text { modified }, i}=T_{O A, \text { original }, i}+T_{\text {change }, i}
$$

where $T_{O A, \text { original, } i}$ is the hourly outdoor air dry-bulb temperature of current TMY3 weather files and $T_{\text {change, } i}$ is the hourly temperature changes, presented in Figure 4.

\subsection{Description of Building Model}

The Department of Energy (DOE)'s flagship building energy modeling software, EnergyPlus version 9.0, is used to model office buildings in the selected climate locations [22]. In this study, the DOE's medium-sized office prototype building model is used to represent all office building types. The office building type is chosen in this study because the building model has the highest construction weights among all other building types (i.e., construction weight of $14.98 \%$ based on 2003-2007 surveyed data in the U.S.) and complies with the minimum energy code requirements prescribed in ASHRAE Standard 90.1-2019 [25,26]. Figure 5 shows a three-dimensional (3D) perspective view and a floor plan of the DOE's medium-sized office prototype model. 
(a)

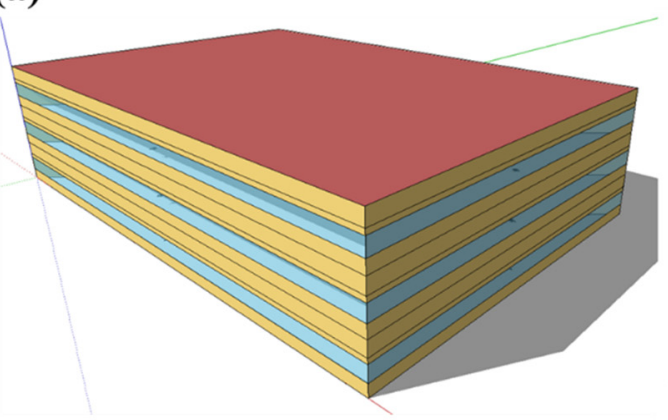

(b)

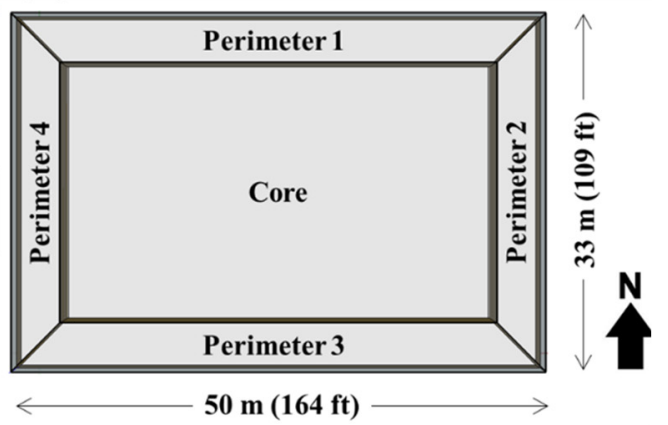

Figure 5. Medium office building model: (a) 3D view and (b) floor plan [8].

The prototype office building is configured as a three-story building with a rectangular floor plan, as shown in Figure 5. Each floor has five (5) thermal zones, including four (4) perimeter zones and one (1) core zone, with a total floor area of $4982 \mathrm{~m}^{2}$. Its construction consists of steel-framed exterior walls, an insulation layer entirely above deck for a flat roof, and slab-on-grade floors. All the construction details and internal heat gains comply with the minimum energy code requirements, i.e., ASHRAE 90.1-2019 [21]. Table 2 summaries representative input parameter and its characteristics of the office model. In terms of a HVAC system, the original prototype office model employs a rooftop unit (RTU) system with variable air volume (VAV) and electric reheat box to meet required heating and cooling loads in each zone of a building, as shown in Figure 5. With a RTU-VAV system, natural gas and electricity are used for a central heating coil and a reheat coil of a VAV reheat box, respectively. For cooling, a direct expansion (DX) cooling coil with two-speed fan operation is used, and the cooling coil requires two sets of performance data to calculate electricity consumption based on the fan speed. All the same performance curves that the original prototype model provides are used in this study. Table 3 summarizes detailed information of the HVAC systems used in the prototype building model.

Table 2. Representative input parameter of the medium-sized office model [22,27].

\begin{tabular}{|c|c|c|c|c|}
\hline \multirow{2}{*}{\multicolumn{2}{|c|}{$\begin{array}{l}\text { Parameter } \\
\text { Location }\end{array}$}} & \multicolumn{3}{|c|}{ Characteristics } \\
\hline & & 4A New York, NY & 5A Buffalo, NY & 6A Rochester, $\mathrm{MN}$ \\
\hline \multicolumn{2}{|l|}{ Total conditioned floor area } & \multicolumn{3}{|c|}{$4982 \mathrm{~m}^{2}$} \\
\hline \multicolumn{2}{|l|}{ Floor-to-ceiling height } & \multicolumn{3}{|c|}{$2.74 \mathrm{~m}$ (1.22 m above-ceiling plenum) } \\
\hline \multicolumn{2}{|l|}{ Window-wall-ratio } & \multicolumn{3}{|c|}{$33 \%$} \\
\hline \multirow{2}{*}{ Window } & U-factor & $0.36 \mathrm{~W} / \mathrm{m}^{2}-\mathrm{K}$ & $0.36 \mathrm{~W} / \mathrm{m}^{2}-\mathrm{K}$ & $0.34 \mathrm{~W} / \mathrm{m}^{2}-\mathrm{K}$ \\
\hline & SHGC & 0.36 & 0.38 & 0.38 \\
\hline \multirow{2}{*}{ Exterior wall construction } & Type & \multicolumn{3}{|c|}{ Steel-frame walls } \\
\hline & U-factor & $0.363 \mathrm{~W} / \mathrm{m}^{2}-\mathrm{K}$ & $0.312 \mathrm{~W} / \mathrm{m}^{2}-\mathrm{K}$ & $0.278 \mathrm{~W} / \mathrm{m}^{2}-\mathrm{K}$ \\
\hline \multirow{2}{*}{ Roof construction } & Type & \multicolumn{3}{|c|}{ Built-up roof: roof membrane, insulation, and metal decking } \\
\hline & U-factor & $0.180 \mathrm{~W} / \mathrm{m}^{2}-\mathrm{K}$ & $0.180 \mathrm{~W} / \mathrm{m}^{2}-\mathrm{K}$ & $0.180 \mathrm{~W} / \mathrm{m}^{2}-\mathrm{K}$ \\
\hline \multirow{2}{*}{ Floor construction } & Type & \multicolumn{3}{|c|}{ Slab-on-grade floors } \\
\hline & U-factor & $0.230 \mathrm{~W} / \mathrm{m}^{2}-\mathrm{K}$ & $0.230 \mathrm{~W} / \mathrm{m}^{2}-\mathrm{K}$ & $0.226 \mathrm{~W} / \mathrm{m}^{2}-\mathrm{K}$ \\
\hline \multicolumn{2}{|l|}{ Occupancy density } & \multicolumn{3}{|c|}{$18.57 \mathrm{~m}^{2} /$ person } \\
\hline \multicolumn{2}{|c|}{ Lighting power density (LPD) } & \multicolumn{3}{|c|}{$6.89 \mathrm{~W} / \mathrm{m}^{2}$} \\
\hline \multicolumn{2}{|c|}{ Equipment power density (EPD) } & \multicolumn{3}{|c|}{$8.1 \mathrm{~W} / \mathrm{m}^{2}$} \\
\hline \multicolumn{2}{|c|}{ Domestic hot water (DHW) system } & \multicolumn{3}{|c|}{ Natural gas water heater with 0.81 of thermal efficiency and constant pump } \\
\hline
\end{tabular}


Table 3. HVAC input parameter of the medium-sized office model $[22,27]$.

\begin{tabular}{ll}
\hline Parameter & Characteristics \\
\hline HVAC type & Rooftop unit (RTU) with variable air volume (VAV) fan and reheat box \\
\hline HVAC heating coil & Natural gas furnace with 0.81 of efficiency \\
\hline HVAC VAV box & Electrical reheat coil with 1.0 of efficiency \\
\hline HVAC cooling coil & Direct expansion-two speed cooling coil with 3.4 of coefficient of performance (COP) \\
\hline Capacity of cooling and heating equipment & Auto-sized based on the design day \\
\hline HVAC fan & Variable air volume fan with 0.6 of efficiency \\
\hline Maximum fan flow rate & Auto-sized based on the design day \\
\hline Zone thermostat set-point & Cooling: $24^{\circ} \mathrm{C} /$ Heating: $21^{\circ} \mathrm{C}$ \\
\hline Zone thermostat set-back & Cooling: $26.7^{\circ} \mathrm{C} /$ Heating: $15.6{ }^{\circ} \mathrm{C}$ \\
\hline
\end{tabular}

Modeling the energy impacts of the building's internal heat gains in EnergyPlus requires assumptions about the internal heat gain intensity and operation schedules. All input values and schedules regarding internal heat gains are directly obtained from the original version of a prototype office model without modifications. Figure 6 shows fraction schedules of representative internal heat gains $[26,27]$ (i.e., lighting, plug, and occupancy), which are used to determine total internal heat gain values inside by simply multiplying the internal heat gain density times its faction value in the time horizon. In addition to the internal heat gains, ASHRAE Standard 90.1-2019 [21] requires additional plug loads consumed by the office building, such as exterior lighting and electricity used by an elevator. All the parts of building energy consumption are considered for NZCB design in this study.

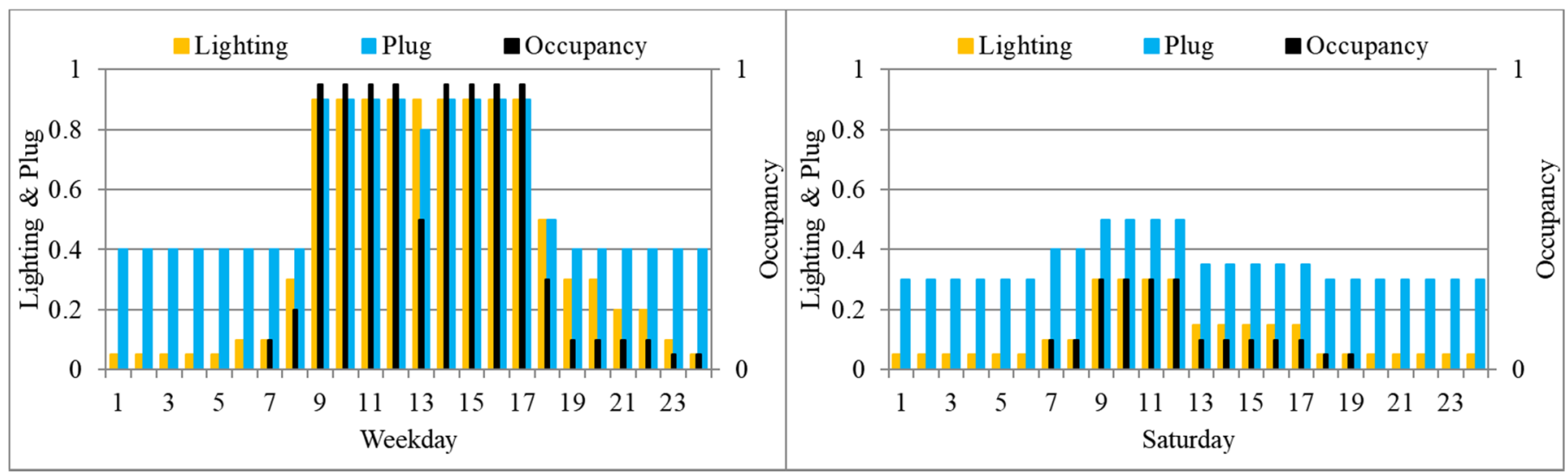

Figure 6. Representative input schedules of the simulation model $[26,27]$.

\subsection{Net-Zero Carbon Building (NZCB) Design}

Net-zero GHG emission building criteria can be achieved when the annual site GHG emission is equal or less than zero. The net GHG emission $\left(E M_{\text {net }}\right)$ can be calculated by:

$$
E M_{n e t}=\sum_{k}\left(E M_{\text {elec-used }, i}+E M_{\text {gas-used }, i}\right)-\sum_{k}\left(E M_{\text {elec-gen }, i}\right)
$$

where $E M_{\text {elec-used, } i}$ and $E M_{\text {gas-used }, i}$ indicate $\mathrm{CO}_{2}$ emission values of the whole building electricity and national gas end-use, respectively, and $i$ varies from 1 to 8760 [hr] for an annual simulation. $E M_{\text {elec-gen, } i}$ is the saved $\mathrm{CO}_{2}$ emission value due to the on-site 
electricity generation. Each emission value can be calculated by multiplying the building electricity and natural gas end-uses times each conversion factor as follows:

$$
\begin{aligned}
E M_{\text {elec-used }} & =E_{\text {elec-used }} \times C F_{\text {elec }} \\
E M_{\text {gas-used }} & =E_{\text {gas-used }} \times C F_{\text {gas }} \\
E M_{\text {elec-gen }} & =E_{P V-\text { gen }} \times C F_{\text {elec }}
\end{aligned}
$$

where $E_{\text {elec-used }}$ and $E_{\text {gas-used }}$ are total building electricity and natural gas end-uses, respectively. $C F_{\text {elec }}$ and $C F_{g a s}$ are emission conversion factors for electricity and natural gas, respectively, in each state. Table 4 shows the U.S. $\mathrm{CO}_{2}$ emission conversion factors by fuel used for this study.

Table 4. U.S. Emission conversion factors by fuel [28].

\begin{tabular}{lll}
\hline Emissions Conversion Factor & Electricity, $C F_{\text {elec }}$ & Natural Gas, $C F_{\text {gas }}$ \\
\hline State of New York & $189.91(\mathrm{~kg} / \mathrm{MWh})$ & \multirow{2}{*}{$181.33(\mathrm{~kg} / \mathrm{MWh})$} \\
\hline State of Minnesota & $454.99(\mathrm{~kg} / \mathrm{MWh})$ & \\
\hline
\end{tabular}

A solar photovoltaic (PV) system is one of the most promising distributed power technologies and can be used on building footprints and building site areas for on-site electricity generation. Although there are many ways to integrate PV systems with a building, this study only considers open area and roof mount types for PV installation with a fixed tilt angle because this comparative study focuses only on climate changes and GHG emission reductions. To enable a NZCB balance, both roof and parking areas are used for solar PV installation locations. This study uses the PVWatts module in EnergyPlus to calculate on-site electricity generation. The PVWatts model is originally developed by the National Renewable Energy Laboratory (NREL), and is a web application and module in NREL's system advisor model software that estimates the electricity generation of a grid-connected PV system for buildings based on a few simple inputs. EnergyPlus uses the same calculation algorithm without any additional needs to call the web application during the calculation process. The hourly available PV production is defined [29] as:

$$
P_{d c, i}=\frac{I_{t r, i}}{1000} P_{d c 0}\left(1+\gamma\left(T_{c e l l, i}-T_{r e f}\right)\right)
$$

where $P_{d c, i}$ and $P_{d c 0}$ indicate hourly generated DC power from the plane-of-array and specified nameplate DC rate, $I_{t r, i}$ is the transmitted irradiance on a cell surface, $\gamma$ is the temperature coefficient, and $T_{\text {cell, } i}$ and $T_{r e f}$ are the computed cell temperature at each time step using a first-principles heat transfer energy balance model developed by Fuentes [30] and the reference cell temperature, respectively. The reference cell temperature is $25^{\circ} \mathrm{C}$, and reference irradiance is $1000 \mathrm{~W} / \mathrm{m}^{2}$ [29,31]. The input values of the PVWatts module used in this study are listed in Table 5.

Table 5. Input parameters of the PVWatts module in EnergyPlus [29,31].

\begin{tabular}{ll}
\hline Field & Used Value \\
\hline System size & Determined DC powers $(\mathrm{kWp})$ (presented in Table 6) \\
Module type & Standard \\
System losses & $14 \%$ \\
Array type & Fixed roof mount \\
Tilt angle & $37^{\circ}$ \\
Azimuth angle & South facing $\left(0^{\circ}\right)$ \\
Inverter DC/AC ratio & 1.1 \\
Inverter efficiency & $96 \%$ \\
\hline
\end{tabular}


Table 6. Maximum power capacity of PV installations to enable NZCBs.

\begin{tabular}{|c|c|c|c|c|}
\hline \multicolumn{2}{|c|}{ Location } & \multirow{2}{*}{$\begin{array}{c}\text { 4A: New York } \\
345.4 \mathrm{kWp}\end{array}$} & \multirow{2}{*}{$\begin{array}{c}\text { 5A: Buffalo } \\
376.1 \mathrm{kWp}\end{array}$} & \multirow{2}{*}{$\begin{array}{c}\text { 6A: Rochester } \\
340.1 \mathrm{kWp}\end{array}$} \\
\hline Original & TMY3 & & & \\
\hline \multirow{2}{*}{ Scenarios } & $2050 \mathrm{~s}$ & $359.6 \mathrm{kWp}$ & $386.7 \mathrm{kWp}$ & $396.4 \mathrm{kWp}$ \\
\hline & $2080 s$ & $354.2 \mathrm{kWp}$ & $395.8 \mathrm{kWp}$ & $388.9 \mathrm{kWp}$ \\
\hline
\end{tabular}

This study chooses the "standard" option because this option represents typical ployor mono-crystalline silicon modules, with efficiencies in the range of $14-17 \%$, which is commonly used for roof mounted PV installation. Losses in the PV system include the impacts of soiling, shading, snow cover, mismatch, wiring, connections, light-induced degradation, nameplate rating, system age, and operational availability [31,32]. This study uses $14 \%$ of the default total system loss, which is provided by the EnergyPlus PVWatts model. The inverter model is based on an analysis of California Energy Commission (CEC) inverter performance data [33]. Hourly AC power outputs can be determined from the DC outputs [29] as:

$$
P_{a c, i}=\left\{\begin{array}{cl}
\eta P_{d c, i} & : 0<P_{d c, i}<P_{d c 0} \\
P_{a c 0} & : P_{d c, i} \geq P_{d c 0} \\
0 & : P_{d c 0}=0
\end{array}\right.
$$

where $\eta$ is the inverter efficiency, $P_{d c, i}$ is the hourly generated DC power outputs from the plane-of-array, $P_{d c 0}$ is the specified nameplate DC rate, and $P_{a c 0}$ is the AC nameplate rating determined from the DC rating of the system and the DC-to-AC ratio. $P_{a c 0}$ can be calculated by simply multiplying $P_{d c 0}$ times $\eta 96 \%$ of the default nominal efficiency used for the calculation in this study.

The electric load center transformer in EnergyPlus allows for feeding the surplus power from on-site power generators to the electrical grid. The load center object matches the voltage between on-site power generation and total electricity used by a building facility. All surplus electricity produced by the PV power generators can be fed back into the electrical grid through the main panel operation that is connected to both the utility grid and on-site power generators of the NZCB. For the transformer performance, the nominal efficiency is set to $97.7 \%$, which is directly obtained from EnergyPlus prototype building's default value [32]. Figure 7 depicts the on-site PV power generators with net-metering operation for the NZCB model.

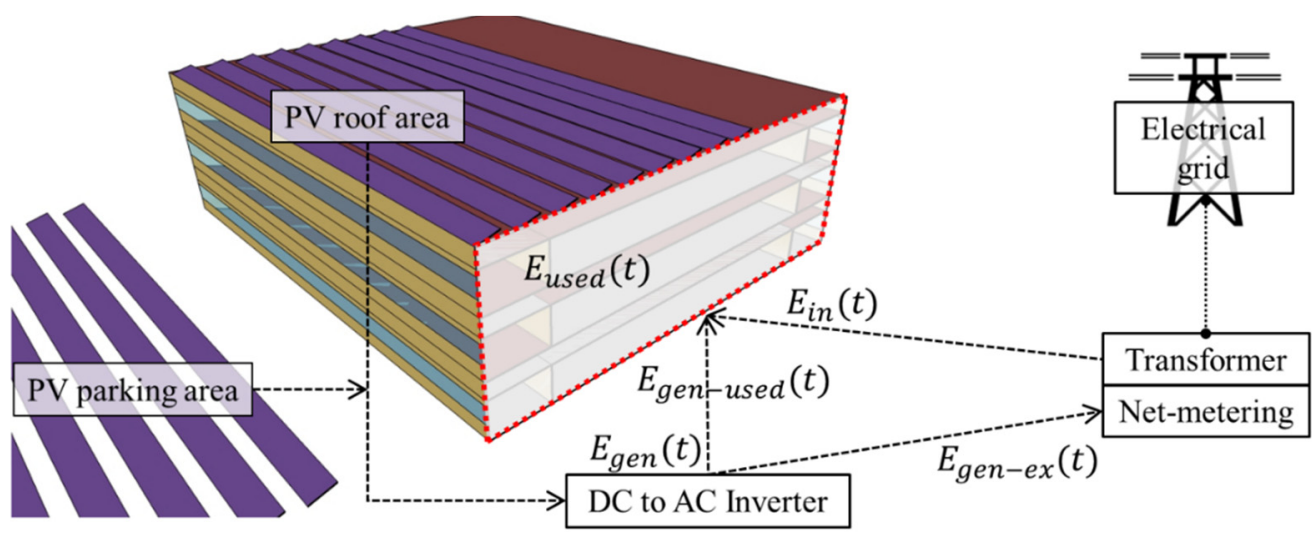

Figure 7. A simulation model with an on-site photovoltaics (PV) system with net-metering to enable net-zero carbon buildings (NZCBs) [10].

\subsection{Simulation Setting Description Based on the Scenarios}

The detailed steps of the simulation setting based on the two scenarios are depicted in Figure 8. The original EnergyPlus prototype office models of each climate location are first simulated with modified weather files of the different scenarios to evaluate its electricity 
and national gas consumption. $\mathrm{CO}_{2}$ emission values are then calculated based on each building's electricity- and natural gas-based emissions.

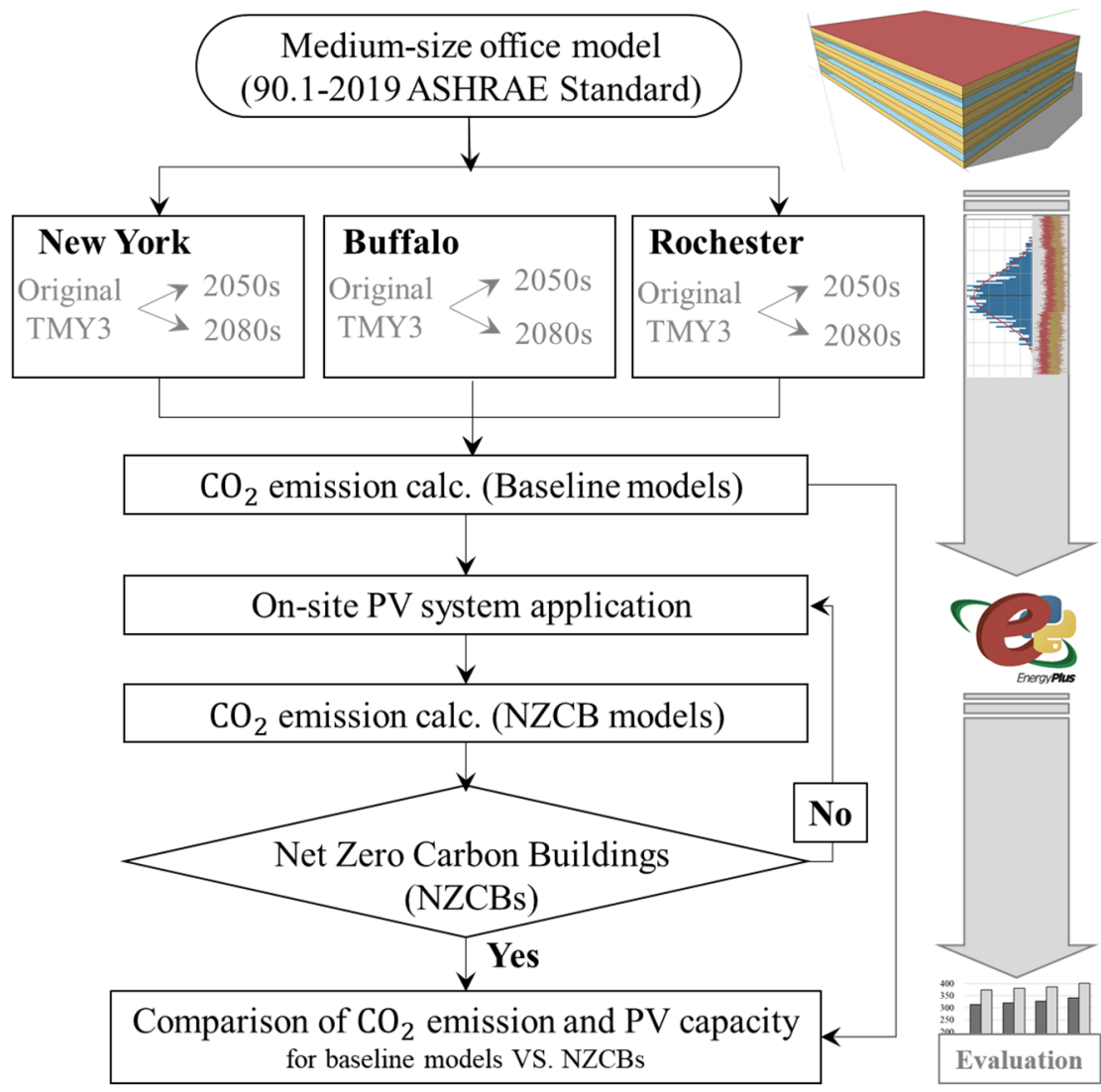

Figure 8. Flowchart of a simulation procedure.

The total maximum PV power outputs installed on both the roof and parking areas of the simulated office model are presented in Table 6 to enable NZCB performance. About $83 \%$ of the entire roof area $\left(1661 \mathrm{~m}^{2}\right)$ is used for the roof-mounted PV installation. Additional PV panels, which are about $3986.4 \mathrm{~m}^{2}$, are installed on parking areas until each simulated model shows satisfactory annual NZCB performance corresponding to each scenario.

It should also be noted that only on-site PV systems are applied to the existing prototype office building model with no technological advance changes to enable NZCBs because the objective of this study is only to investigate the future climate change's impacts on electricity and natural gas energy consumption and thus the potential need of PV capacity for NZCB performance. This simplified way can give precise insight into how the current office building model itself reacts to the future climate changes for the potential enabling of a zero carbon emission building with the scenarios over the coming decades.

\section{Results and Discussion}

This section presents and discusses results obtained from building energy simulations of NZCBs under the different climate change scenarios in the U.S. Northeast and Midwest regions. There are two climate change scenarios updated from TMY3 weather data based on future changes obtained from the proposed climate change model. Those scenarios are applied in a conventional office building model (i.e., DOE' medium office prototype building model) to estimate energy consumption and GHG emission as a baseline. Then the baseline office building model is designed to be the NZCB with the PV-based renewable energy generation system. A comparative analysis is conducted to determine the capacity of the on-site PV system to enable net zero carbon balance. The following sections present 
the climate data obtained from the proposed climate change model, energy performance, GHG emission results for climate change scenarios determined from the prototype office building models, and the potential need for on-site PV system capacities to enable the NZCBs with the climate change scenarios over a yearly cycle.

\subsection{Climate Change Data}

In this section, the profiles of generated hourly dry-bulb temperatures are presented. Each climate location has three different temperature profiles, including the original TMY3. The hourly temperature profiles of the two scenarios are developed based on Equation (2), Figure 9 depicts the hourly profiles of new generated outdoor air dry-bulb temperatures for two scenarios and three climate locations. The temperature rises in hourly temperature profiles throughout all scenarios and climate locations can be recognized because of the rises in monthly projected outdoor air temperatures, as shown in Figure 1. Those temperature profiles, as shown in Figure 9, generated by the random distribution are used to create new TMY3 weather files and the weather flies are then applied to building energy simulation for the comparative analysis of NZCBs. Note that the impact of other parameters, such as solar radiation and wind speed, in the TMY weather file is not reflected in this study when creating new weather files because the try bulb temperature is the most influential parameter factor to evaluate building energy consumption, especially when HVAC energy usages are focused.

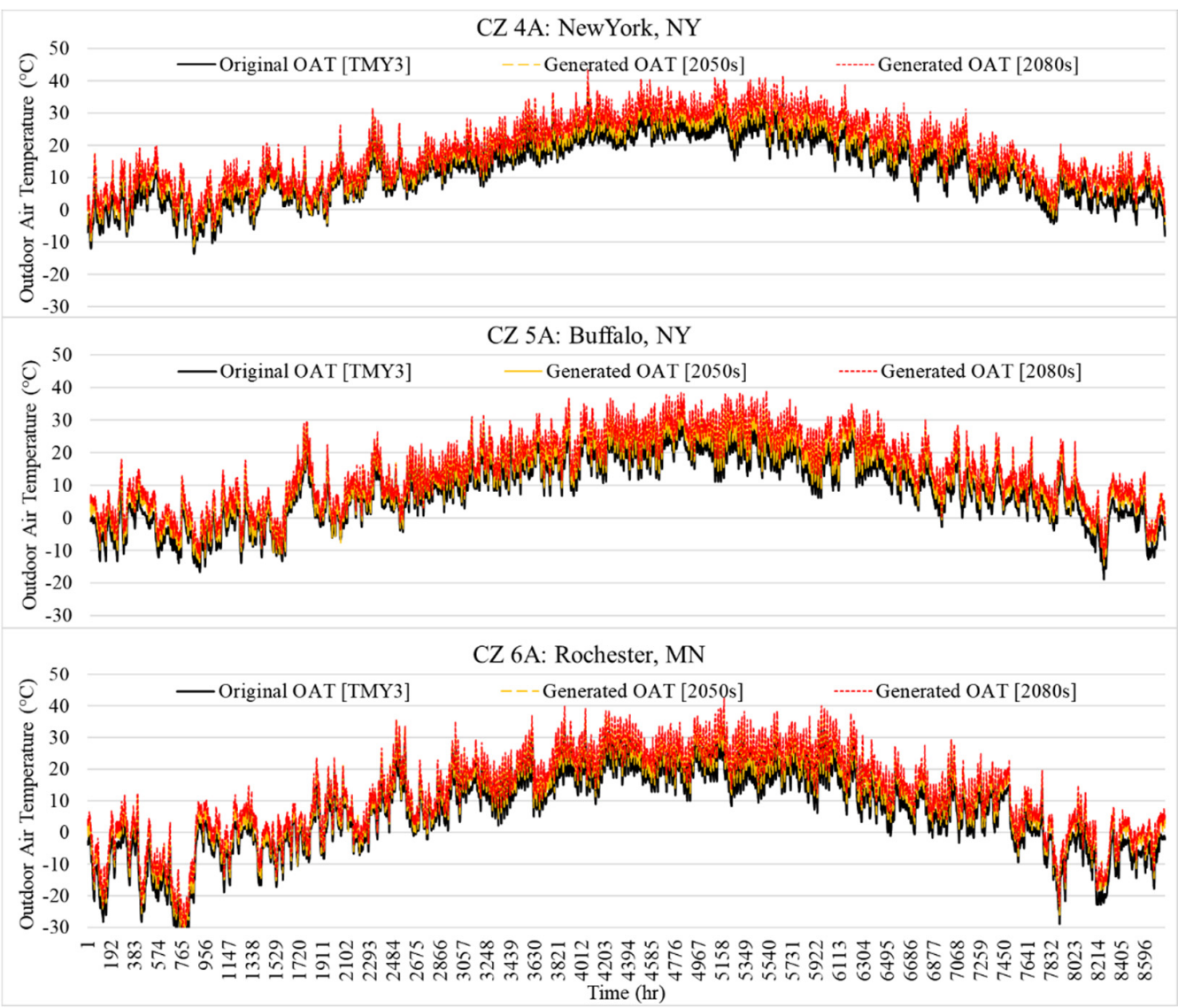

Figure 9. Profiles of generated outdoor air temperatures (OATs) for the scenarios in each climate location.

Based on the dry-bulb temperatures shown in Figure 9, the design day weather data were derived by determining the maximum and minimum temperatures of the scenario in the 2050s and 2080s in design-day months. The design day information is used for sizing the HVAC systems in Section 2.2. The design day information for the baseline and scenario in the 2050s and 2080s for the selected locations are provided in Table 7. 
Table 7. Climate zones and its design-day weather information.

\begin{tabular}{|c|c|c|c|c|}
\hline \multirow{2}{*}{ Climate Zone (CZ) } & \multirow{2}{*}{ City, State } & \multirow{2}{*}{ Scenario } & \multicolumn{2}{|c|}{ Design Day Dry-Bulb Temperature } \\
\hline & & & Heating $\left({ }^{\circ} \mathrm{C}\right)$ & Cooing $\left({ }^{\circ} \mathrm{C}\right)$ \\
\hline \multirow{3}{*}{$4 \mathrm{~A}$} & \multirow{3}{*}{ New York, NY } & TMY3 & -10.7 & 32.1 \\
\hline & & 2050s & -6.8 & 35.6 \\
\hline & & $2080 s$ & -4.7 & 38.2 \\
\hline \multirow{3}{*}{$5 \mathrm{~A}$} & \multirow{3}{*}{ Buffalo, NY } & TMY3 & -16.3 & 30.3 \\
\hline & & 2050s & -12.4 & 33.8 \\
\hline & & $2080 s$ & -10.3 & 36.4 \\
\hline \multirow{3}{*}{$6 \mathrm{~A}$} & \multirow{3}{*}{ Rochester, NY } & TMY3 & -26.2 & 31.2 \\
\hline & & 2050s & -22.3 & 34.7 \\
\hline & & 2080s & -20.2 & 37.3 \\
\hline
\end{tabular}

\subsection{Energy Use Intensity (EUI) of Baseline Model}

This section compares the annual whole building EUIs of conventional baseline building models for the original weather file versus the two scenarios in the three U.S. climate locations. There are two energy source types in the prototype office building model, including electricity and natural gas. Space heating and domestic hot water (DHW) systems use natural gas as an energy source, while all other parts use electricity in the model. Figure 10 shows the detailed breakdown of annual building EUIs with the unit of $\mathrm{kWh} / \mathrm{m}^{2}$-year. As expected, EUIs from HVAC systems (i.e., heating and cooling) vary significantly depending on the climate changes while EUIs for the other part remains almost the same. For example, in the 5A climate condition, increases of the cooling EUIs are $64 \%$ and $122 \%$ for the scenario in the 2050s and 2080s, respectively, whereas the heating EUIs show $31 \%$ and $47 \%$ of reductions corresponding to each scenario when compared to the original weather condition. The results from the other two climate locations (i.e., $4 \mathrm{~A}$ and $6 \mathrm{~A}$ ) also indicate that similar trends are followed. The results indicate that there are significant impacts of climate changes on the HVAC energy consumption, thus it could be observed that GHG emission would vary primarily depending on HVAC energy usages. However, it should be noted that the total annual building EUIs do not show large differences when compared to the original case as shown in Figure 10 because the cooling EUI increases as the heating EUI decreases. Also note that the heating EUI consists of two fuel types, including electricity and natural gas, from VAV reheat coils and central heating coils, respectively. Since it is expected that changes in GHG emission generated by buildings primarily depend on heating and cooling energy usages, GHG emission variation by energy source types is also analyzed in this study. The annual EUIs of baseline models by the energy source type are presented in Figure 11 with the unit of $\mathrm{kWh} / \mathrm{m}^{2}$-year. The results of all the climate locations indicate that the annual electricity usages tend to increase, as expected, while the annual gas usages show a decreased trend corresponding to climate change scenarios. 


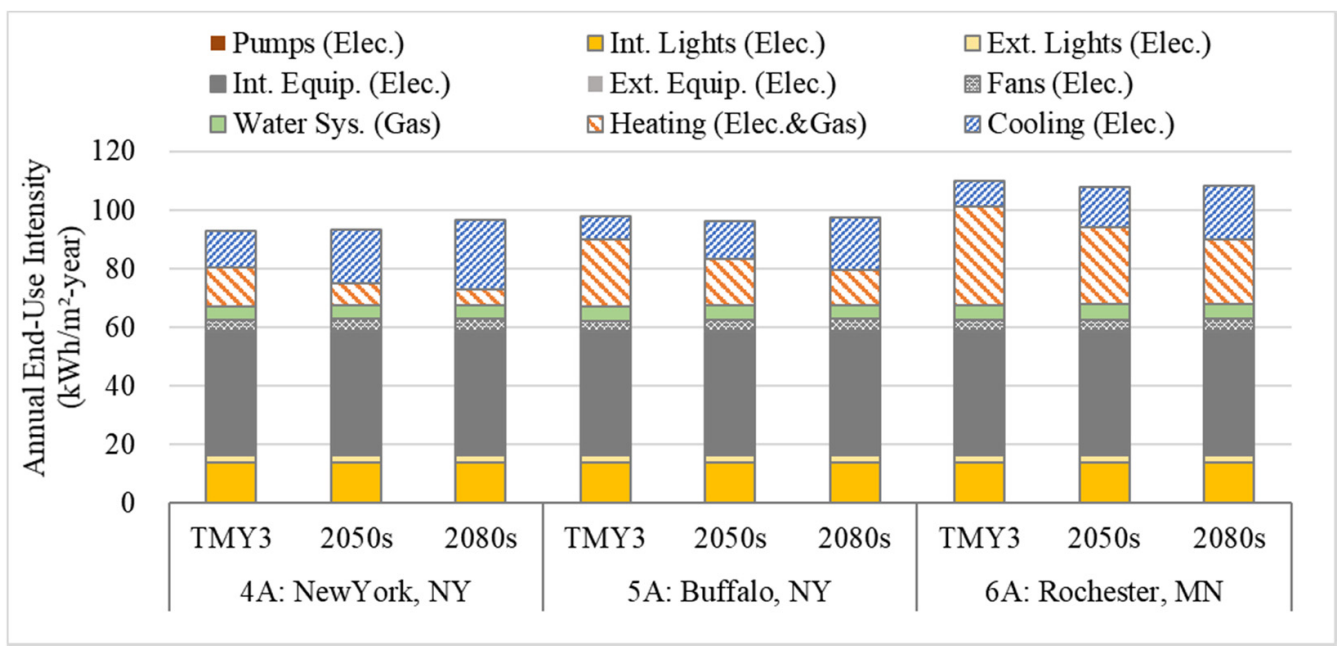

Figure 10. Annual whole building Energy Use Intensity (EUI) of baseline models.

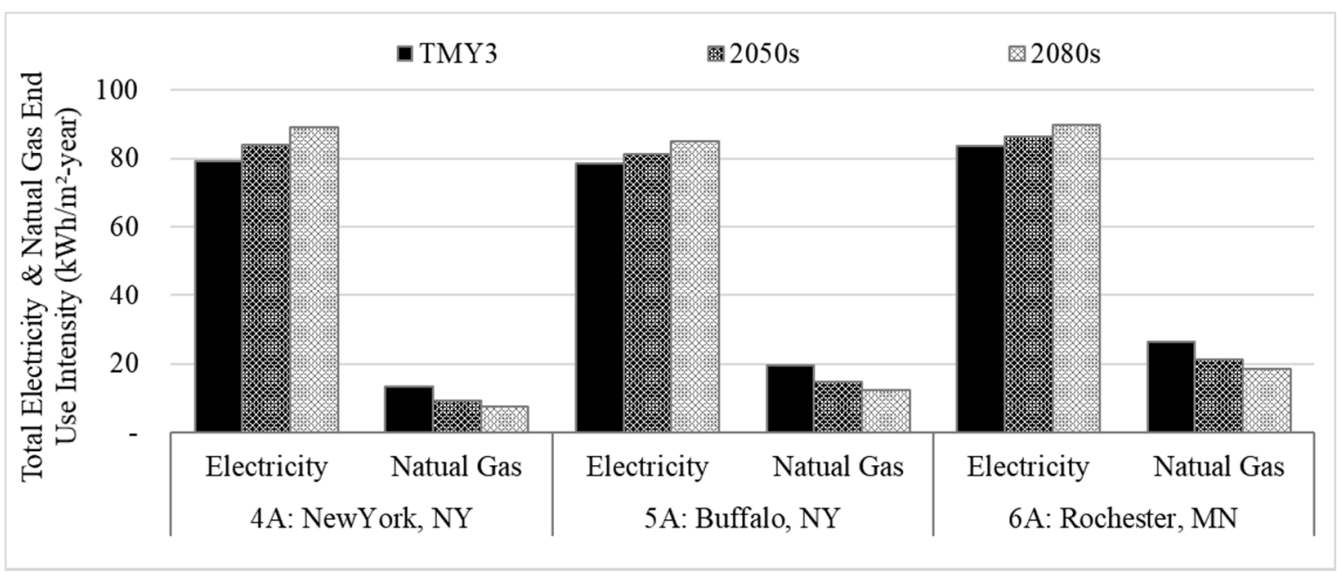

Figure 11. Annual electricity and natural gas energy use intensity of baseline models.

\subsection{GHG Emission of Baseline Model by Energy Source Type}

Annual GHG emission values of each energy source type for the scenarios and climate locations in the building are determined by Equation (4) and Equation (5), respectively. Figures 12 and 13 present annual GHG emission values of baseline building models by energy source types and HVAC parts. In Figure 12, the GHG emission values from the electricity consumption show increased patterns and that the natural gas consumption shows reduced values as the scenario of climate changes moves further towards the 2050s and 2080s, whereas the total building EUIs do not vary significantly. For example, in climate $4 \mathrm{~A}$, increases in the GHG emission values from the electricity are 6.7 and 13.0 tons of $\mathrm{CO}_{2}$-eq for the 2050s and 2080s scenario, respectively, when compared to the original TMY3 weather condition. Reductions in those from the natural gas are 6.8 and 9.92 tons of $\mathrm{CO}_{2}$-eq for the 2050s and 2080s scenarios, respectively, when compared to the original weather condition. The results from other two climate locations (i.e., $5 \mathrm{~A}$ and $6 \mathrm{~A}$ ) also show similar patterns of increases and decreases in GHG emission values, but the amount of GHG emission values of the 6A location is much higher than the others due to the emission conversion factor of electricity. 


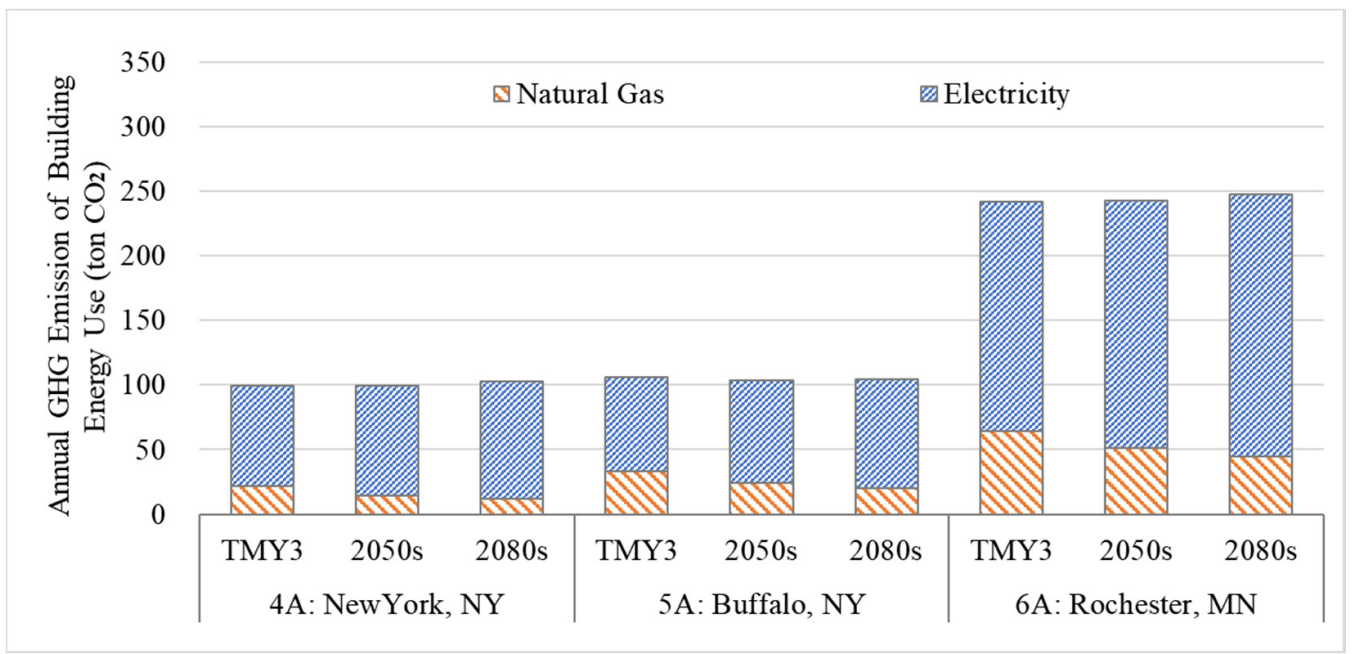

Figure 12. Annual embodied greenhouse gas (GHG) emission of baseline models by energy source type.

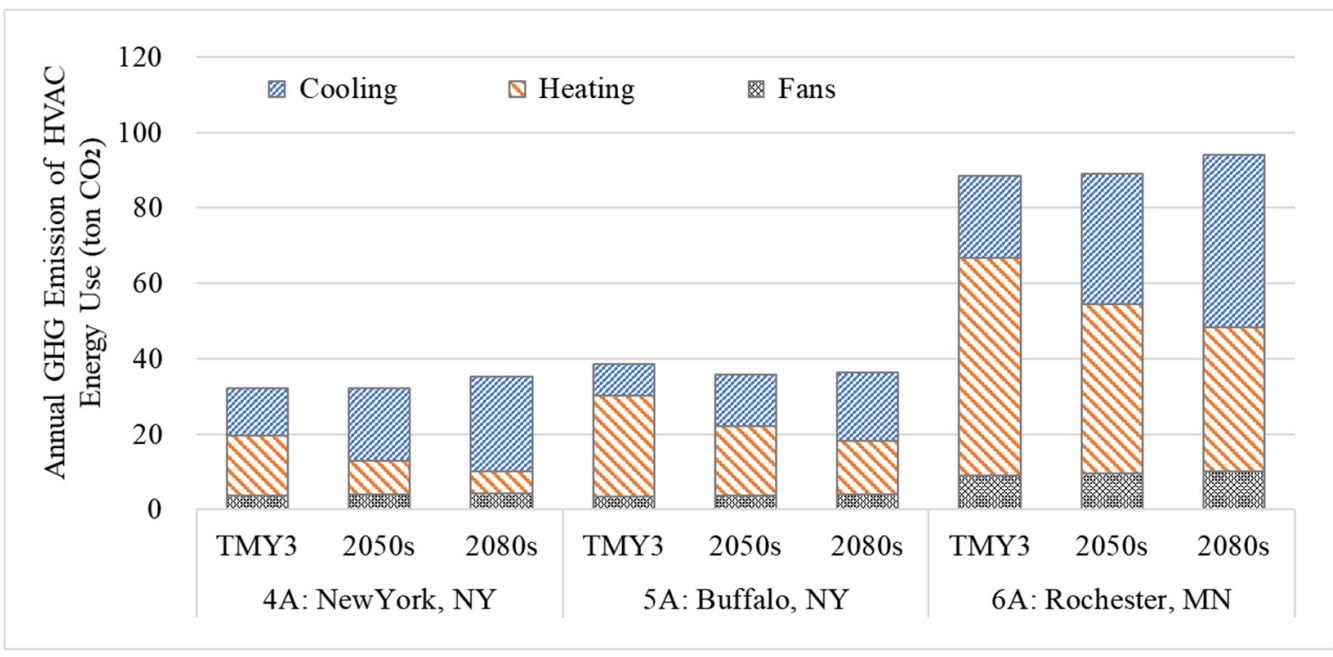

Figure 13. Annual GHG emission of baseline models by HVAC components.

Figure 13 depicts annual GHG emission values of baseline models by HVAC components for each scenario and location with the unit of ton $\mathrm{CO}_{2}$-eq. From this figure, changes in the GHG emission by HVAC fan energy usages are shown to be relatively low when compared to the original TMY3. However, the changes of GHG emission in HVAC heating and cooling energy usages are significant. In climate $5 \mathrm{~A}$, increases in the GHG emission values from cooling energy use are 5.3 and 10.0 tons of $\mathrm{CO}_{2}$-eq for scenarios in the 2050s and 2080s, respectively, when compared to the original case. In terms of GHG emission from HVAC fan energy use in $5 \mathrm{~A}$, it indicates that there are 0.3 and 0.5 tons of $\mathrm{CO}_{2}$-eq for scenarios in the 2050s and 2080s, respectively, when compared to the original case. Note that the GHG emission values of electricity and national gas energy usages presented in this section are used as the baseline to further develop to NZCBs.

\subsection{GHG Emission and PV Installation for NZCB}

This section discusses variations of GHG emission values when the prototype office building models achieve the performance of NZCBs corresponding to each scenario and climate location. The PV installation capacities needed to enable NZCB goals is also presented in this section. Figure 14 depicts the scatter plots of each NZCB performance corresponding to each scenario and location with the unit of ton $\mathrm{CO}_{2}$-eq. The annual 
GHG emission from the baseline building energy end-use is compared against that from on-site power generation to investigate carbon emission balances for each scenario and location. The ratio of $y$-axis to $x$-axis should be one or greater to reach zero carbon emission performance, as shown in Figure 14. It is observed that all the cases of the building model present acceptable net zero carbon balances. The GHG emissions of NZCBs are in the ranges of 80-120 tons for climate zones $4 \mathrm{~A}$ and $5 \mathrm{~A}$ and $220-260$ tons for climate zone $6 \mathrm{~A}$, respectively. Since the GHG emission of the whole building's energy end-use is determined based on electricity and natural gas usages, both electricity and gas consumed in a building need to be considered to calculate acceptable NZCB balances. Figure 14 also presents the near NZCB balances that considers only electricity consumption.

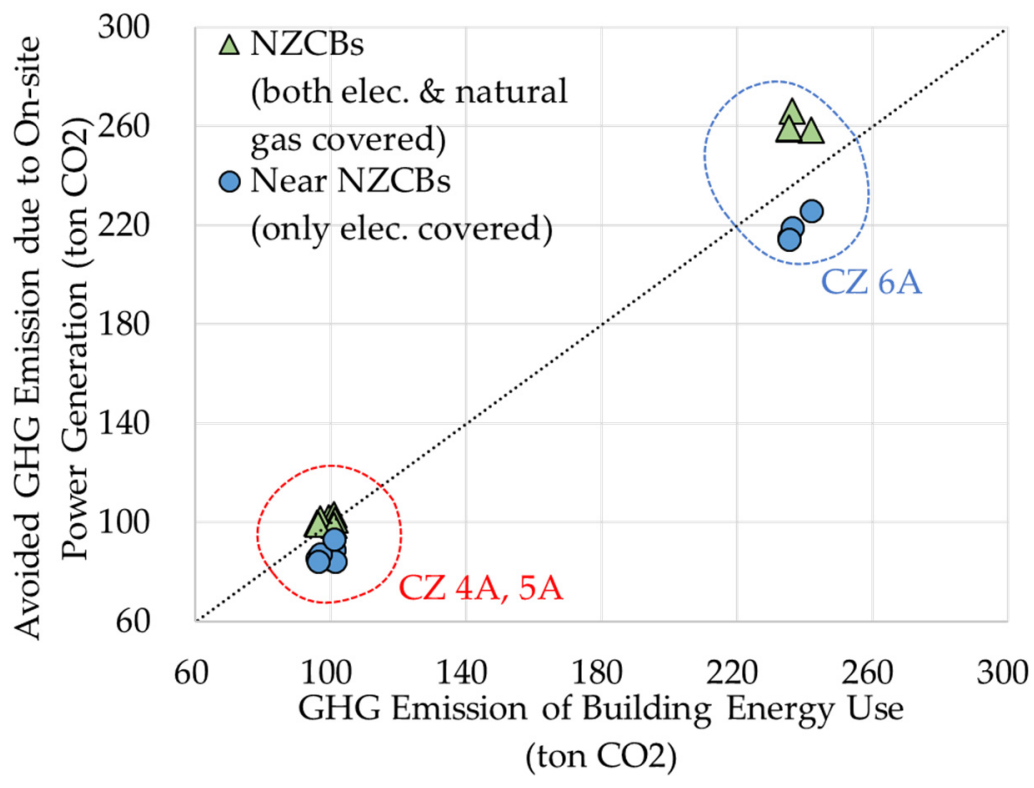

Figure 14. GHG emission balance for NZCB designs in climate zones (CZ).

Equation (3) is used to determine the total PV installation capacities needed for the NZCB goals by offsetting all GHG emissions from the electricity and natural gas consumption of the building model. Figure 15 depicts the capacities of on-site PV installation and its GHG emission intensities to enable the zero carbon emission balances. This figure shows that the capacity of PV installation to offset the GHG emission from the electricity consumption is significantly higher than that from the natural gas consumption in all climate locations.

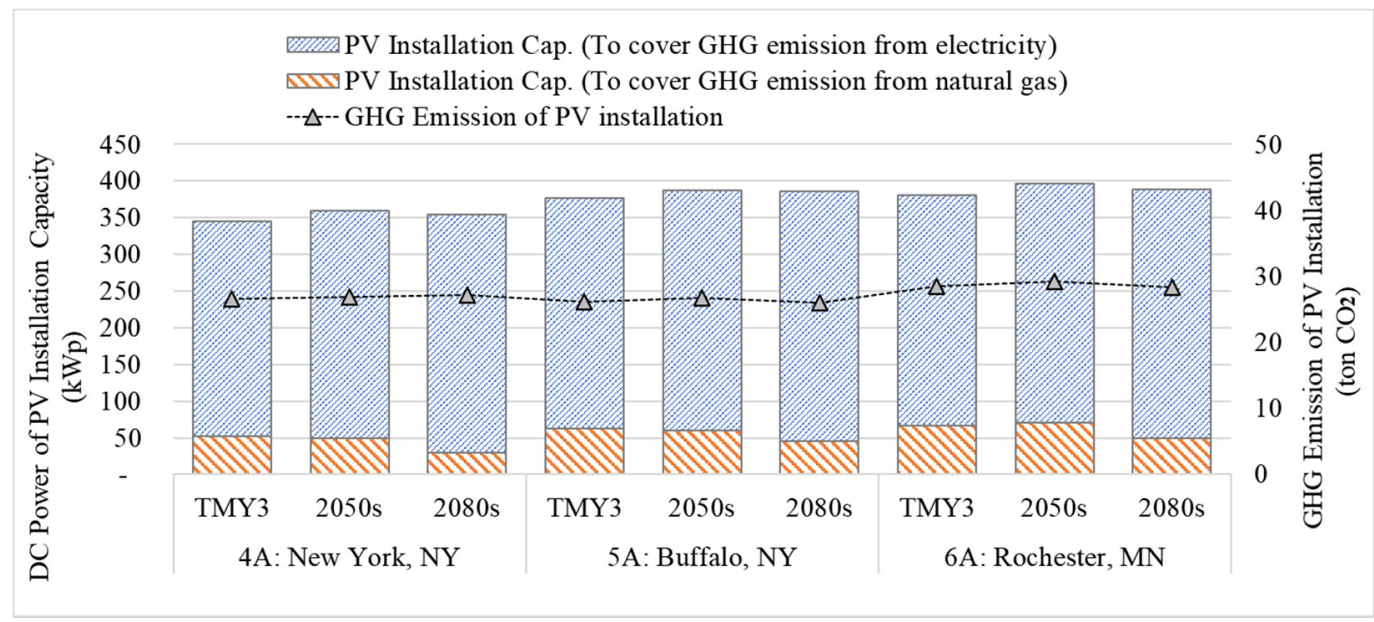

Figure 15. PV installation capacity and its GHG emission intensity to enable NZCBs. 
As expected, the PV capacities of covering the electricity's GHG emission tend to increase gradually according to the climate change scenarios mainly due to rises in outdoor air temperatures. For example, in Buffalo (climate zone 4A), 314, 327, and $341 \mathrm{kWp}$ of PV installation capacities are shown for the climate scenarios of original TMY3, 2050s, and 2080s, respectively. Conversely, for the PV capacities to cover GHG emission from the national gas usage, it is shown that the 2080s scenarios present the lowest capacities, which are relatively higher reductions when compared to other cases. For example, in the climate $4 \mathrm{~A}$ case, $46 \mathrm{kWp}$ of PV installation capacities is needed to offset the GHG emission from natural gas, whereas about $60 \mathrm{kWp}$ of PV installation capacity is needed for the other scenarios (i.e., TMY3 and 2050s) in the location. The results from the other two climate locations (i.e., $5 \mathrm{~A}$ and $6 \mathrm{~A}$ ) also show similar patterns of increases and decreases in the PV installation capacities to offset GHG emission values. In addition, Figure 15 presents GHG emission generated from PV installations. A total of $50 \mathrm{~g} \mathrm{CO}_{2}$-eq/ $\mathrm{kWh}$ of GHG intensity obtained from $[34,35]$ is used to calculate the GHG emission of PV installation in this study. These results indicate that the emission of PV installation is about one order of magnitude lower than the emission produced by the building energy consumption.

\section{Conclusions}

This study investigated the impacts of potential future climate changes on annual building energy use intensities and GHG emission in the U.S. Northeast and Midwest climate locations. It also analyzed renewable design requirements to enable NZCBs under future climate scenarios using an on-site PV system. The Gaussian random distribution method was used to develop climate change scenarios with monthly temperature change values over the whole Northeast and Midwest regions, which were developed based on a high GHG emission scenario (i.e., the representative concentration pathways (RCP) 8.5). A simulation-based study of a prototype office building was conducted to evaluate the annual electricity and natural gas usages of the building models in different climate locations in the U.S. Northeast and Midwest regions. The PV-based on-site power generation system was considered and applied to the simulated building model to enable NZCB performance by assuming net-metering operation under future climate scenarios. Appropriate capacities of the on-site PV power system for reaching NZCB balances were required to be determined according to the energy source types of building energy consumption. The amount of GHG emission from the electricity or natural gas usages of the office building model could vary significantly depending on future climate scenarios. The capacities of the on-site PV systems for NZCBs could also vary based on a combined effect of annual building energy usages in each location and climate scenario, the emission conversion factors, and solar irradiation availability in each climate location. Key findings from this study are as follows:

- The simulated office building models that comply with the minimum energy code requirements of ASHRAE Standard 90.1-2019 presented around 79-84 kWh $/ \mathrm{m}^{2}$-year and $13-26 \mathrm{kWh} / \mathrm{m}^{2}$-year for the annual electricity and natural gas energy usages, respectively, in U.S. Northeast and Midwest climate locations. As the future climate scenarios of 2050s and 2080s were applied, the amount of annual electricity consumption tended to increase gradually from the baseline year climate conditions, whereas that of annual natural gas use decreased gradually toward the future years. This is primarily because of increases in outdoor air temperatures of climate change data used in the building simulations, which led to increases in the cooling energy consumption in the building, decreasing in heating energy usages;

- The GHG emission trends in each climate followed the same pattern as the trends of the energy source type energy consumption (i.e., electricity and natural gas) changes toward the future climate scenarios. The emission by electricity consumption increased by, moving toward the future scenarios, up to about 25 tons of $\mathrm{CO}_{2}$-eq (about $14 \%$ of the total $\mathrm{CO}_{2}$ produced by the electricity energy source) while the emission produced by the natural gas consumption in the building decreased by up to about 20 tons of $\mathrm{CO}_{2}$-eq (about $30 \%$ of the total $\mathrm{CO}_{2}$-eq produced by the natural gas energy source). 
The total GHG emission of the building in each climate location remained relatively even in all climate scenarios, although each climate location showed a different level of the emission rate. Depending on the climate conditions and electricity emission conversion factors in different climate locations, the same building can generate more emissions as the climate scenarios toward 2050s and 2080s as shown in the results of the New York case (climate zones 4A and 5A) in Figures 13 and 14;

- The capacities of on-site PV systems required to enable NZCBs can differ depending on the local climate conditions (i.e., temperature and irradiation) and climate change scenarios as shown in shown in Figure 15 although the total PV capacity responsible by all energy source types did not change significantly (i.e., less than about a $15 \mathrm{kWp}$ increase of the total PV capacity to offset the GHG emissions in the different climate scenarios). The building models of climate zone $4 \mathrm{~A}$ used around $345-360 \mathrm{kWp}$ for the zero-carbon emission target, while the other two climates (i.e., 5A and 6A) showed similar trends of PV capacities, including 376-387 kWp and 380-396 kWp for climate $5 \mathrm{~A}$ and $6 \mathrm{~A}$, respectively. The results in Figure 15 also showed that the PV installation capacity to offset the emission account for the electricity consumption increases significantly up to about $40 \mathrm{kWp}$ (i.e., up to more than $10 \%$ of total PV installation capacities) as the different climate change scenarios were applied.

Such results from this study could provide useful insights into not only GHG emission generated from the electricity and national gas consumption of office buildings under different future climate scenarios in the selected climate locations, but also renewable design requirements (i.e., the capacity of on-site PV systems) when the office buildings were considered for the NZCB design. From the results, it can be concluded that the cooling energy consumption would significantly impact GHG emissions as future potential climate scenarios are considered. Consequently, the designers of NZCBs should consider highly efficient cooling energy systems in their designs to reduce the renewable energy generation system capacity to achieve net-zero carbon emission goals.

It should be noted that there are limitations in this study, including that (a) only outdoor air dry-bulb temperature was used as a weather data parameter for developing the climate change model, and (b) the studied climate regions were limited within the U.S. Northeastern and Midwestern areas mainly due to the limited information of future climate change data in other regions of the U.S. Based on this study, future work can be extended to include various climate parameters in the whole building simulation analysis to reflect climate change scenarios in higher resolutions and improve the estimation of building energy consumptions and renewable energy requirements for NZCBs. Furthermore, all U.S. climate locations could be considered for a national scale analysis of NZCBs.

Author Contributions: Conceptualization, H.C. and D.K.; methodology, H.C., P.J.M. and D.K.; software and simulation, H.C., D.K. and H.L.; formal analysis, D.K.; investigation, H.C. and P.J.M.; resource, H.C., J.Y.; writing-original draft, D.K.; writing-review and editing, H.C., P.J.M., and J.Y.; visualization, H.C. and D.K. All authors have read and agreed to the published version of the manuscript.

Funding: This research received no external funding.

Data Availability Statement: The data presented in this study are available within this article.

Acknowledgments: The work was supported by the Korea Institute of Energy Technology Evaluation and planning (KETEP) and the Ministry of Trade, Industry \& Energy (MOTIE) of the Republic of Korea (No. 20204030200080), the Department of Mechanical Engineering at Mississippi State University (MSU), and the Department of Mechanical and Aerospace Engineering at West Virginia University (WVU).

Conflicts of Interest: The authors declare no conflict of interest. 


\section{References}

1. U.S. Energy Information Administration. Monthly Energy Review. 2020; Volume 0035. Available online: https:/ /www.eia.gov / totalenergy/data/monthly/pdf/mer.pdf (accessed on 19 September 2020).

2. U.S. Energy Information Administration. EIA Energy Outlook 2020 with Projections to 2050. 2020. Available online: https: //www.eia.gov/outlooks/aeo/pdf/AEO2020\%20Full\%20Report.pdf (accessed on 19 September 2020).

3. CSR. U.S. Carbon Dioxide Emissions in the Electricity Sector: Factors, Trends, and Projections. 2019. Available online: https: / / crsreports.congress.gov (accessed on 19 September 2020).

4. De Chalendar, J.A.; Taggart, J.; Benson, S.M. Tracking emissions in the US electricity system. Proc. Natl. Acad. Sci. USA 2019, 116, 25497-25502. [CrossRef] [PubMed]

5. U.S. Global Change Research Program. Climate Science Special Report: Fourth National Climate Assessment; Global Change Research Program: Washington, DC, USA, 2018; Volume 1, p. 470. [CrossRef]

6. Jäger-Waldau, A.; Kougias, I.; Taylor, N.; Thiel, C. How photovoltaics can contribute to GHG emission reductions of $55 \%$ in the EU by 2030. Renew. Sustain. Energy Rev. 2020, 126. [CrossRef]

7. Collins, M.; Knutti, R.; Arblaster, J.; Dufresne, J.-L.; Fichefet, T.; Friedlingstein, P.; Gao, X.; Gutowski, W.J.; Tim, J.; Krinner, G.; et al. Chapter 12: Long-Term Climate Change: Projections, Commitments and Irreversibility; Cambridge University Press: Cambridge, UK; New York, NY, USA, 2014; Available online: https:/ /www.ipcc.ch/report/ar5/wg1/long-term-climate-change-projectionscommitments-and-irreversibility/ (accessed on 9 August 2020).

8. Kim, D.; Cho, H.; Koh, J.; Im, P. Net-zero energy building design and life-cycle cost analysis with air-source variable refrigerant flow and distributed photovoltaic systems. Renew. Sustain. Energy Rev. 2020, 118, 109508. [CrossRef]

9. Pylsy, P.; Lylykangas, K.; Kurnitski, J. Buildings' energy efficiency measures effect on $\mathrm{CO}_{2}$ emissions in combined heating, cooling and electricity production. Renew. Sustain. Energy Rev. 2020, 134, 110299. [CrossRef]

10. Kim, D.; Cho, H.; Luck, R. Potential impacts of net-zero energy buildings with distributed photovoltaic power generation on the U.S. electrical grid. J. Energy Resour. Technol. ASME 2019, 141, 1-15. [CrossRef]

11. Reich, N.H.; Alsema, E.A.; van Sark, W.G.J.H.M.; Nieuwlaar, E. $\mathrm{CO}_{2}$ Emissions of PV in the perspective of a Renewable Energy Economy. In Proceedings of the 22nd European Photovoltaic Solar Energy Conference, Milan, Italy, 3-7 September 2017; pp. 3538-3542.

12. Louwen, A.; van Sark, W.G.J.H.M.; Faaij, A.P.C.; Schropp, R.E.I. Re-assessment of net energy production and greenhouse gas emissions avoidance after 40 years of photovoltaics development. Nat. Commun. 2016, 7, 1-9. [CrossRef] [PubMed]

13. Pinel, D.; Korpås, M.; Lindberg, K.B. Impact of the $\mathrm{CO}_{2}$ factor of electricity and the external $\mathrm{CO}_{2}$ compensation price on zero emission neighborhoods' energy system design. Build. Environ. 2021, 187. [CrossRef]

14. Wan, K.K.W.; Li, D.H.W.; Lam, J.C. Assessment of climate change impact on building energy use and mitigation measures in subtropical climates. Energy 2011, 36, 1404-1414. [CrossRef]

15. Nik, V.M.; Kalagasidis, A.S. Impact study of the climate change on the energy performance of the building stock in Stockholm considering four climate uncertainties. Build. Environ. 2013, 60, 291-304. [CrossRef]

16. Kikumoto, H.; Ooka, R.; Arima, Y.; Yamanaka, T. Study on the future weather data considering the global and local climate change for building energy simulation. Sustain. Cities Soc. 2015, 14, 404-413. [CrossRef]

17. Shen, P. Impacts of climate change on U.S. building energy use by using downscaled hourly future weather data. Energy Build. 2017, 134, 61-70. [CrossRef]

18. Wang, L.; Liu, X.; Brown, H. Prediction of the impacts of climate change on energy consumption for a medium-size office building with two climate models. Energy Build. 2017, 157, 218-226. [CrossRef]

19. Summa, S.; Tarabelli, L.; Ulpiani, G.; Perna, C. Impact of Climate Change on the Energy and Comfort Performance of nZEB: A Case Study in Italy. Climate 2020, 8, 125. [CrossRef]

20. Good, C.; Kristjansdottír, T.; Wiberg, A.H.; Georges, L.; Hestnes, A.G. Influence of PV technology and system design on the emission balance of a net zero emission building concept. Sol. Energy 2016, 130, 89-100. [CrossRef]

21. ASHRAE. Energy Standard for Buildings Except Low-Rise Residential Buildings (I-P); ANSI/ASHRAE/IES Standard No. 90.1-2019; ASHRAE: Atlanta, GA, USA, 2019.

22. US DOE. Commercial Prototype Building Models I Building Energy Codes Program; U.S. Department of Energy: Washington, DC, USA, 2013. Available online: https://www.energycodes.gov/development/commercial/prototype_models (accessed on 4 March 2020).

23. Yun, K.; Luck, R.; Mago, P.J.; Cho, H. Building hourly thermal load prediction using an indexed ARX model. Energy Build. 2012, 54, 225-233. [CrossRef]

24. Byun, K.; Chiu, C.M.; Hamlet, A.F. Effects of 21st century climate change on seasonal flow regimes and hydrologic extremes over the Midwest and Great Lakes region of the US. Sci. Total Environ. 2019, 650, 1261-1277. [CrossRef]

25. Wilcox, S.; Marion, W. Users Manual for TMY3 Data Sets. 2008. Available online: https://www.nrel.gov/docs/fy08osti/43156.pdf (accessed on 4 March 2020).

26. Goel, S.; Rosenberg, M.; Athalye, R.; Xie, Y. Enhancements to ASHRAE Standard 90.1 Prototype Building Models; Pacific Northwest National Laboratory (PNNL): Richland, WA, USA, 2014. Available online: http:/ /www.energycodes.gov/sites/default/files/ documents/PrototypeModelEnhancements_2014_0.pdf (accessed on 18 August 2019). 
27. Thornton, B.; Wang, W.; Xie, Y.; Cho, H.; Liu, B.; Zhang, J. Achieving the 30\% Goal: Energy and Cost Savings Analysis of ASHRAE Standard; Technical Report: PNNL-20405; Pacific Northwest National Laboratory (PNNL): Richland, WA, USA, 2011.

28. U.S. Environmental Protection Agency (EPA). Emission \& Generation Resource Integrated Database (eGRID): EGRID Summary Tables. Available online: https:/ / www.epa.gov/egrid/egrid-summary-tables (accessed on 19 December 2020).

29. US DOE. EnergyPlus Version 9.0 Documentation: EnergyPlus Engineering Reference; U.S. Department of Energy: Washington, DC, USA, 2019.

30. Fuentes, M.K. A Simplified Thermal Model for Flat-Plate Photovoltaic Arrays; Technical Report: SAND85-0330; Sandia National Laboratories: Albuquerque, NM, USA, 1987. Available online: https:/ / prod-ng.sandia.gov/techlib-noauth/access-control.cgi/ 1985/850330.pdf (accessed on 18 August 2019).

31. Dobos, A.P. PVWatts Version 5 Manual; Technical Report: NREL-TP-6A20-62641; National Renewable Energy Laboratory (NREL): Denver, CO, USA, 2014. Available online: http:/ / www.nrel.gov/docs/fy14osti/62641.pdf (accessed on 18 August 2019).

32. US DOE. EnergyPlus Version 9.0 Documentation: EnergyPlus Input and Output Reference; U.S. Department of Energy: Washington, DC, USA, 2019.

33. CCE. California Public Utilities Commission Rule. Available online: http://www.gosolarcalifornia.org (accessed on 18 August 2020).

34. Nugent, D.; Sovacool, B.K. Assessing the lifecycle greenhouse gas emissions from solar PV and wind energy: A critical metasurvey. Energy Policy 2014, 65, 229-244. [CrossRef]

35. NREL. Life Cycle Greenhouse Gas Emissions from Solar Photovoltaics. Renew. Sustain. Energy Rev. 2012, 50, 80. Available online: https:/ / www.nrel.gov/docs/fy13osti/56487.pdf (accessed on 19 October 2020). 